\title{
Characterization of the sulphate mineral coquimbite, a secondary iron sulphate from Javier Ortega mine, Lucanas Province, Peru - Using infrared, Raman spectroscopy and thermogravimetry
}

\author{
Ray L. Frost ${ }^{\mathrm{a}, *}$, Željka Žigovečki Gobac ${ }^{\mathrm{b}}$, Andrés López ${ }^{\mathrm{a}}$, Yunfei Xi ${ }^{\mathrm{a}}$, Ricardo Scholz ${ }^{\mathrm{c}}$, Cristiano Lana ${ }^{\mathrm{c}}$, \\ Rosa Malena Fernandes Lima ${ }^{\mathrm{d}}$

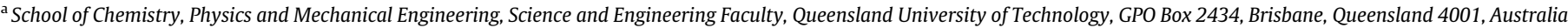 \\ ${ }^{\mathrm{b}}$ Institute of Mineralogy and Petrography, Department of Geology, Faculty of Science, University of Zagreb, Horvatovac 95, 10000 Zagreb, Croatia

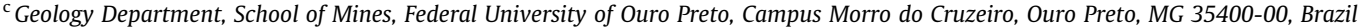 \\ ${ }^{\mathrm{d}}$ Mining Engineering Department, School of Mines, Federal University of Ouro Preto, Campus Morro do Cruzeiro, Ouro Preto, MG 35400-00, Brazil
}

H I G H L I G H T S

- We have studied the mineral coquimbite.

- Using SEM with EDX, thermal analytical techniques and Raman and infrared spectroscopy.

- Chemical formula was determined as $\left(\mathrm{Fe}_{1.37}^{3+}, \mathrm{Al}_{0.63}\right)_{\sum 2.00}\left(\mathrm{SO}_{4}\right)_{3} \cdot 9 \mathrm{H}_{2} \mathrm{O}$.

- Thermal analysis showed a total mass loss of $\sim 73.4 \%$ on heating to $1000{ }^{\circ} \mathrm{C}$.

\section{A R T I C L E I N F O}

\section{Article history:}

Received 19 November 2013

Received in revised form 30 January 2014

Accepted 30 January 2014

Available online 3 February 2014

\section{Keywords:}

Coquimbite

Amarantite

Raman spectroscopy

Sulphate

Infrared spectroscopy

\begin{abstract}
A B S T R A C T
The mineral coquimbite has been analysed using a range of techniques including SEM with EDX, thermal analytical techniques and Raman and infrared spectroscopy. The mineral originated from the Javier Ortega mine, Lucanas Province, Peru. The chemical formula was determined as $\left(\mathrm{Fe}_{1.37}^{3+}, \mathrm{Al}_{0.63}\right)_{2.00}\left(\mathrm{SO}_{4}\right)_{3} \cdot 9 \mathrm{H}_{2} \mathrm{O}$. Thermal analysis showed a total mass loss of $\sim 73.4 \%$ on heating to $1000{ }^{\circ} \mathrm{C}$. A mass loss of $30.43 \%$ at $641.4^{\circ} \mathrm{C}$ is attributed to the loss of $\mathrm{SO}_{3}$. Observed Raman and infrared bands were assigned to the stretching and bending vibrations of sulphate tetrahedra, aluminium oxide/hydroxide octahedra, water molecules and hydroxyl ions. The Raman spectrum shows well resolved bands at 2994, 3176, 3327, 3422 and $3580 \mathrm{~cm}^{-1}$ attributed to water stretching vibrations. Vibrational spectroscopy combined with thermal analysis provides insight into the structure of coquimbite.
\end{abstract}

(c) 2014 Elsevier B.V. All rights reserved.

\section{Introduction}

Coquimbite is an iron (III) sulphate mineral of ideal formula $\mathrm{Fe}_{2}^{3+}\left(\mathrm{SO}_{4}\right)_{3} \cdot 9 \mathrm{H}_{2} \mathrm{O}$, which derives its name from the Coquimbo region, Chile [1]. Coquimbite is found as secondary mineral developed in the oxidized portions of weathering iron sulphide deposits in arid regions, although it could be also found associated with fumarolic activity [1]. The mineral was first described from Tierra Amarilla near Copiapó, Chile [2-5], and other occurrences were reported in Quetena, Chuquicamata, Alcaparrosa, Chile; Concepción mine, Huelva, Spain; Skouriotisa, Cyprus; Rammelsberg, Hartz, Germany, among others [1,3,6-8].

\footnotetext{
* Corresponding author. Tel.: +61 731382407; fax: +61 731381804

E-mail address: r.frost@qut.edu.au (R.L. Frost).
}

Coquimbite was recently found in Peru, at the Javier Ortega mine, Lucanas Province, Departmento Ayacucho [9]. Main ore mineral in Javier Ortega mine is chalcopyrite and secondary ore minerals are sphalerite and galena [9]. Coquimbite occurs in the oxidized portions of this iron sulphide deposit, together with other secondary sulphate minerals like alunogen, chalcanthite, copiapite, halotrichite, jarosite, krausite, römerite and with sulphur. Coquimbite in Javier Ortega mine occurs in well developed violet crystals up to $5 \mathrm{~cm}$ long [9].

Coquimbite is a hexagonal mineral $[10,11]$ with $a=10.922(9)$, $c=17.084(14) \AA$, space group $P \overline{3} 1 c$ and $Z=4$ [12]. Ideal formula of this mineral is $\mathrm{Fe}_{2}^{3+}\left(\mathrm{SO}_{4}\right)_{3} \cdot 9 \mathrm{H}_{2} \mathrm{O}$, but there is often a replacement of $\mathrm{Fe}^{3+}$ by $\mathrm{Al}^{3+}$, so the formula of this mineral should be written $\mathrm{Fe}_{2 x}^{3+} \mathrm{Al}_{x}\left(\mathrm{SO}_{4}\right)_{3} \cdot 9 \mathrm{H}_{2} \mathrm{O}$ [6,12]. There are three outstanding features of the coquimbite structure. The dominant structural 
feature is a discontinuous chain, composed of alternating Fe octahedra and $S$ tetrahedra, parallel to, and approximately one-half the length of, the $c$ axis. The symmetry causes the chain to be repeated in the upper one-half of the cell. The individual chain segments (i.e.

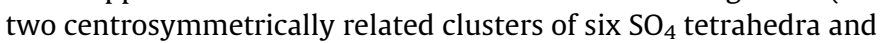
three Fe octahedra in each unit cell) are linked through hydrogen bonds only. The second structural feature is the geometrical arrangement of these chains which gives rise to "channels", paralleling the $a_{1}$ and $a_{2}$ axes, which are occupied by water molecules linked to the chains by hydrogen bonds. The third structural feature are independent ( $\mathrm{Al}, \mathrm{Fe}$ ) octahedra located at the origin and at the centre of the $c$ edges surrounded by six $\mathrm{H}_{2} \mathrm{O}$ molecules. There are three crystallographically different iron atoms octahedrally coordinated to six $\mathrm{O}$ and/or $\mathrm{Ow}$ (= oxygen atom of an $\mathrm{H}_{2} \mathrm{O}$ molecule) forming $\mathrm{Fe} 1 \mathrm{O}_{6}, \mathrm{Fe}_{2} \mathrm{O}_{3} \mathrm{Ow}_{3}$, and $\mathrm{Fe} 3 \mathrm{Ow} 1_{6}$ octahedra. Two of in total three crystallographically independent $\mathrm{H}_{2} \mathrm{O}$ molecules, Ow1 and Ow3 are bonded to one iron atom, whereas Ow2 is not bonded to any cation. The mean $\langle\mathrm{Fe}-\mathrm{O}\rangle$ distance of $\mathrm{Fe} 3$ site differ from distances of $\mathrm{Fe} 1$ and $\mathrm{Fe} 2$ sites, and such a difference in average bond distance can be attributed to the partial Fe3 site occupation also by $\mathrm{Al}$ atoms. So, the crystal structure of coquimbite could be described as a $\left[\mathrm{Fe}_{4}\left(\mathrm{H}_{2} \mathrm{O}\right)_{12}\left(\mathrm{SO}_{4}\right)_{6}\right]^{0}$ framework consisting of $\left[\mathrm{Fe} 1 \mathrm{Fe}_{2}\left(\mathrm{H}_{2} \mathrm{O}\right)_{6}\left(\mathrm{SO}_{4}\right)_{6}\right]^{3-}$ clusters and isolated $\left[\mathrm{Fe} 3\left(\mathrm{H}_{2} \mathrm{O}\right)_{6}\right]^{3+}$ octahedra connected to each other only by hydrogen bonds. Ow1 and Ow3 atoms are engaged in the further interconnection of the $\left[\mathrm{Fe}_{3}\right.$ $\left.\mathrm{Ow}_{6}\left(\mathrm{SO}_{4}\right)_{6}\right]$ clusters and [FeOw1 $1_{6}$ ] octahedra. And Ow2 atoms which build hydrogen-network-bonded $\mathrm{H}_{2} \mathrm{O}$ molecules $\left(\mathrm{H}_{2} \mathrm{Ow} 2\right)$ which are placed in channels running parallel to the $a$ axis (in cages made by channel's intersection) occupy positions which can be compared to the corners of a flattened octahedron and there can be distinguished two bonding-scheme types for this Ow2 atoms, i.e. two hydrogen-bonded network variants around the $\mathrm{H}_{2} \mathrm{Ow} 2$ molecules [13].

Rietveld refinement of the coquimbite structure [14] on a sample from the Richmond mine, Redding, California, proved that there is, together with the Al-for-Fe substitution on Fe3 site, also a minor Al-for-Fe substitution on the Fe1 site. Although there is a possibility of a wide range of continuous replacement of the $\mathrm{Fe}^{3+}$ by other ions of similar radius, such as especially aluminium, without modifying the structural type, on increasing the Al content beyond a certain limit, a structural rearrangement of the phase occurs, leading to the new mineral species aluminocoquimbite $\mathrm{AlFe}^{3+}\left(\mathrm{SO}_{4}\right)_{3} \cdot 9 \mathrm{H}_{2} \mathrm{O}$ [15-17]. Mineral coquimbite is polytypic with paracoquimbite, a rhombohedral mineral (space group $R \overline{3}$ ) [18]. These two minerals, i.e. two layer-like crystal structures differ in layer stacking sequences, with a repeat distance of 8.5 Å between structurally identical but spatially transposed layers.

Approximately 370 sulphate-mineral species are known to exist in nature and they are found in a variety of geological settings, including volcanic, hydrothermal, evaporitic, and chemical-weathering environments [19]. A problem in identification of such minerals with techniques like an X-ray diffraction arrives when closely related minerals are found in paragenetic relationship [20]. So, vibrational spectroscopic techniques are applicable in identification of such paragenetically related minerals.

\section{Experimental procedure}

\subsection{Samples description and preparation}

The mineral coquimbite studied in this work was obtained from the collection of the Geology Department of the Federal University of Ouro Preto, Minas Gerais, Brazil, with sample code SAB-101. The sample is from the Javier Ortega mine, Lucanas Province, Peru.
The sample was gently crushed and the associated minerals were removed under a stereomicroscope Leica MZ4. The coquimbite sample was phase analysed by X-ray diffraction. Scanning electron microscopy (SEM) was applied to support the mineralogical chemical.

\subsection{Scanning electron microscopy (SEM)}

Coquimbite cleavage fragments were coated with a $5 \mathrm{~nm}$ layer of evaporated Au. Secondary Electron and Backscattering Electron

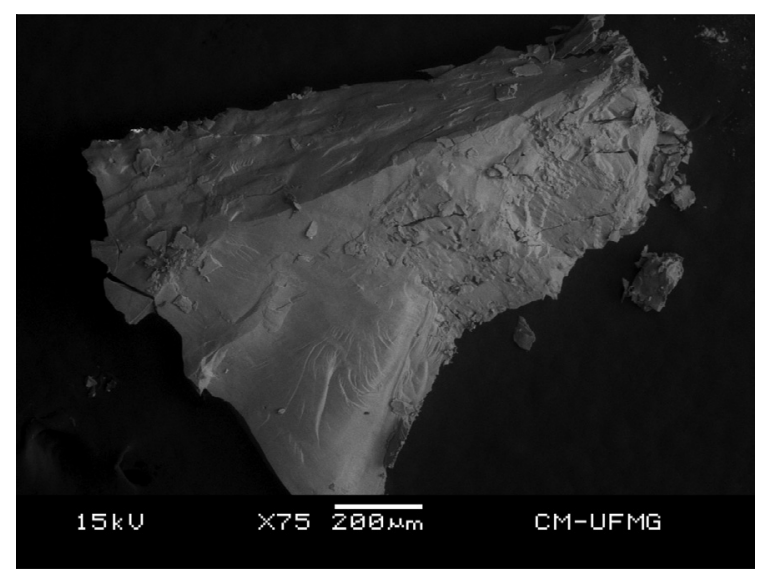

Fig. 1. Backscattered electron image (BSI) of a coquimbite crystal aggregate up to $0.5 \mathrm{~mm}$ in length.

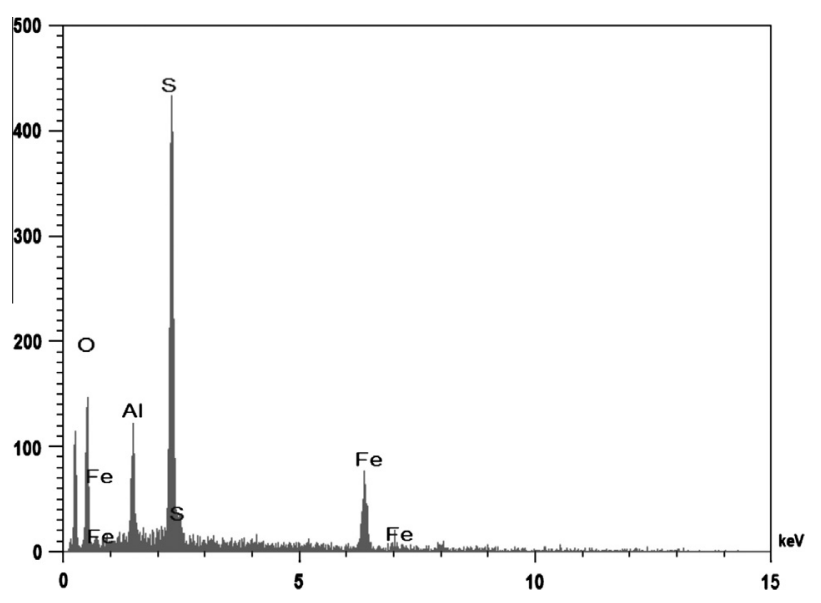

Fig. 2. EDS analysis of coquimbite.

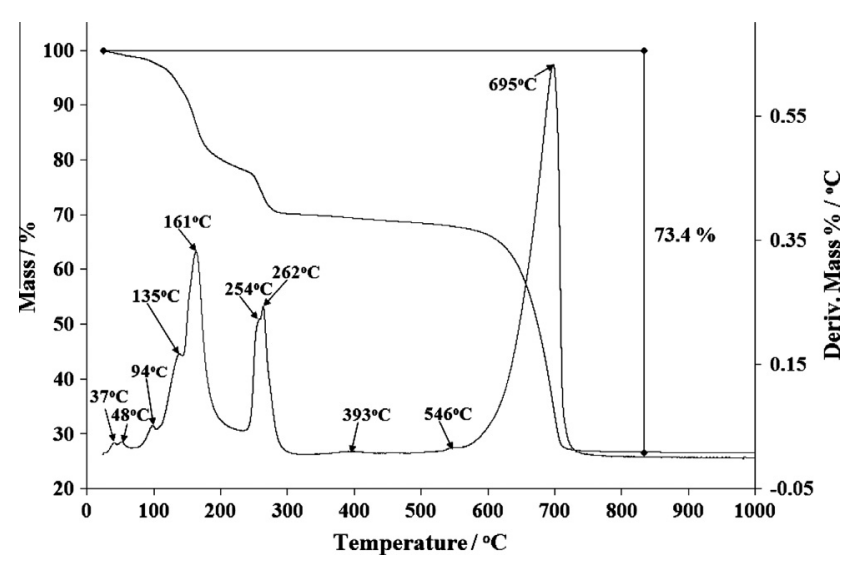

Fig. 3. Thermal analysis of coquimbite. 



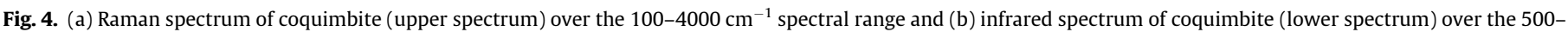
$4000 \mathrm{~cm}^{-1}$ spectral range.

images were obtained using a JEOL JSM-6360LV equipment. Qualitative and semi-quantitative chemical analyses in the EDS mode were performed with a ThermoNORAN spectrometer model Quest and were applied to support the mineral characterization.

\subsection{Thermogravimetric analysis - TG/DTG}

Thermogravimetric analysis of the coquimbite mineral were obtained by using TA Instruments Inc. Q50 high-resolution TGA operating at a $10^{\circ} \mathrm{C} / \mathrm{min}$ ramp with data sample interval of $0.50 \mathrm{~s} / \mathrm{pt}$ from room temperature to $1000{ }^{\circ} \mathrm{C}$ in a high-purity flowing nitrogen atmosphere $\left(100 \mathrm{~cm}^{3} / \mathrm{min}\right)$. A mass of about $28.0 \mathrm{mg}$ of finely ground dried sample was heated in an open platinum crucible.

\subsection{Raman spectroscopy}

Crystals of coquimbite were placed on a polished metal surface on the stage of an Olympus BHSM microscope, which is equipped with $10 \times, 20 \times$, and $50 \times$ objectives. The microscope is part of a Renishaw 1000 Raman microscope system, which also includes a monochromator, a filter system and a CCD detector (1024 pixels). The Raman spectra were excited by a Spectra-Physics model 127 He-Ne laser producing highly polarised light at $633 \mathrm{~nm}$ and collected at a nominal resolution of $2 \mathrm{~cm}^{-1}$ and a precision of
Table 1

Table of the Raman and infrared bands and their assignments.

\begin{tabular}{|c|c|c|}
\hline $\begin{array}{l}\text { Raman peak position } \\
\left(\mathrm{cm}^{-1}\right)\end{array}$ & $\begin{array}{l}\text { Infrared peak position } \\
\left(\mathrm{cm}^{-1}\right)\end{array}$ & Band assignment \\
\hline 3580 & 3678 & OH stretching \\
\hline 3422 & 3536 & \\
\hline 3327 & 3424 & Water stretching \\
\hline 3176 & 3288 & \\
\hline 2994 & 3096 & \\
\hline 1661 & 1651 & Water bending \\
\hline 1201 & 1172 & $\mathrm{SO}_{4}^{2-} \mathrm{v}_{3}$ \\
\hline 1165 & 1161 & $\begin{array}{l}\text { Antisymmetric } \\
\text { stretching }\end{array}$ \\
\hline 1113 & 1100 & \\
\hline 1095 & 1060 & \\
\hline \multicolumn{3}{|l|}{1037} \\
\hline 1025 & 1024 & $\begin{array}{l}\mathrm{SO}_{4}^{2-} v_{1} \text { symmetric } \\
\text { stretching }\end{array}$ \\
\hline \multirow[t]{4}{*}{1015} & 1011 & \\
\hline & 1002 & \\
\hline & 942 & Water librational \\
\hline & 828 & \\
\hline 673 & 701 & \\
\hline 620 & 668 & \\
\hline 599 & & \\
\hline 525 & & $\mathrm{SO}_{4}^{2-} \mathrm{v}_{4}$ bending \\
\hline
\end{tabular}


Table 1 (continued)

\begin{tabular}{|c|c|c|}
\hline $\begin{array}{l}\text { Raman peak position } \\
\left(\mathrm{cm}^{-1}\right)\end{array}$ & $\begin{array}{l}\text { Infrared peak position } \\
\left(\mathrm{cm}^{-1}\right)\end{array}$ & Band assignment \\
\hline \multicolumn{3}{|l|}{508} \\
\hline \multicolumn{3}{|l|}{498} \\
\hline 463 & & $\mathrm{SO}_{4}^{2-} \mathrm{v}_{2}$ bending \\
\hline \multicolumn{3}{|r|}{ 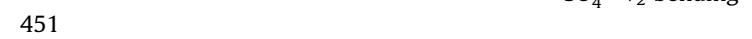 } \\
\hline \multicolumn{3}{|l|}{414} \\
\hline 321 & & $\begin{array}{l}\text { Metal-oxygen } \\
\text { stretching }\end{array}$ \\
\hline \multicolumn{3}{|l|}{284} \\
\hline 260 & & Lattice vibrations \\
\hline \multicolumn{3}{|l|}{251} \\
\hline \multicolumn{3}{|l|}{211} \\
\hline \multicolumn{3}{|l|}{201} \\
\hline \multicolumn{3}{|l|}{186} \\
\hline \multicolumn{3}{|l|}{172} \\
\hline \multicolumn{3}{|l|}{164} \\
\hline \multicolumn{3}{|l|}{151} \\
\hline \multicolumn{3}{|l|}{141} \\
\hline 108 & & \\
\hline
\end{tabular}

$\pm 1 \mathrm{~cm}^{-1}$ in the range between 200 and $4000 \mathrm{~cm}^{-1}$. Repeated acquisitions on the crystals using the highest magnification $(50 \times)$ were accumulated to improve the signal to noise ratio of the spectra. Raman Spectra were calibrated using the $520.5 \mathrm{~cm}^{-1}$ line of a silicon wafer. The Raman spectrum of at least 10 crystals was collected to ensure the consistency of the spectra.

\subsection{Infrared spectroscopy}

Infrared spectra were obtained using a Nicolet Nexus 870 FTIR spectrometer with a smart endurance single bounce diamond ATR cell. Spectra over the $4000-525 \mathrm{~cm}^{-1}$ range were obtained by the co-addition of 128 scans with a resolution of $4 \mathrm{~cm}^{-1}$ and a mirror velocity of $0.6329 \mathrm{~cm} / \mathrm{s}$. Spectra were co-added to improve the signal to noise ratio.

Spectral manipulation such as baseline correction/adjustment and smoothing were performed using the Spectracalc software package GRAMS (Galactic Industries Corporation, NH, USA). Band component analysis was undertaken using the Jandel 'Peakfit' software package that enabled the type of fitting function to be selected and allows specific parameters to be fixed or varied accordingly. Band fitting was done using a Lorentzian-Gaussian cross-product function with the minimum number of component bands used for the fitting process. The Gaussian-Lorentzian ratio was maintained at values greater than 0.7 and fitting was undertaken until reproducible results were obtained with squared correlations of $r^{2}$ greater than 0.995 .
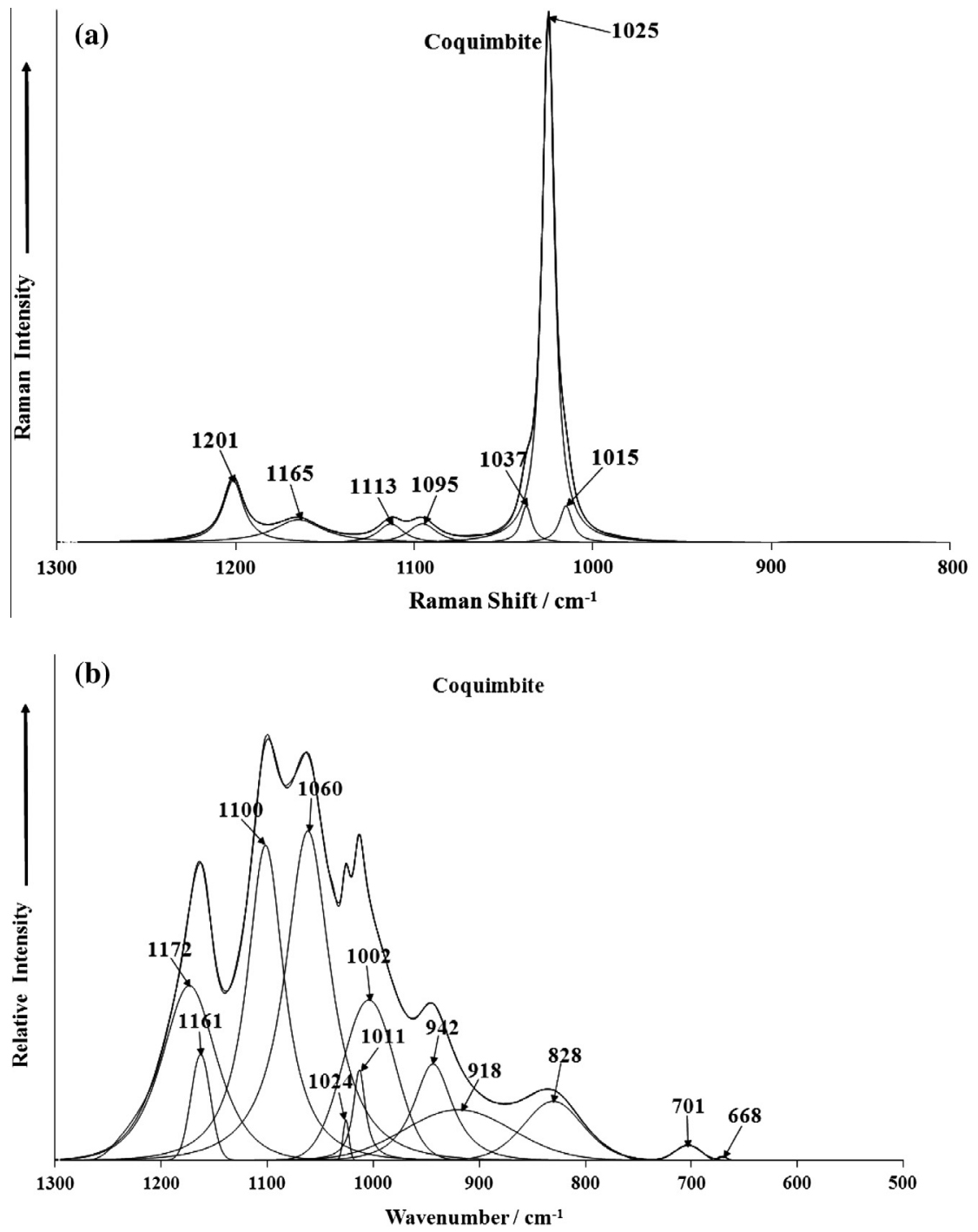

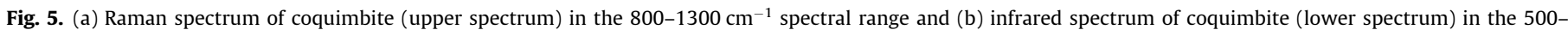
$1300 \mathrm{~cm}^{-1}$ spectral range. 




(b)

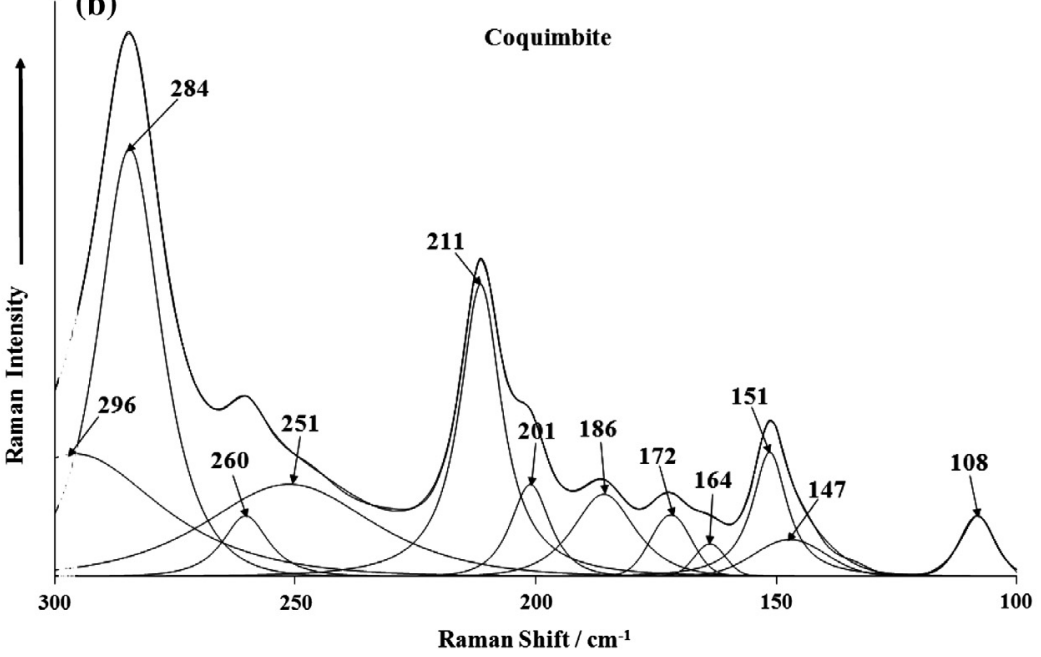

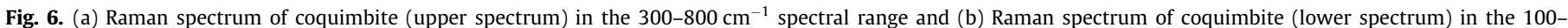
$300 \mathrm{~cm}^{-1}$ spectral range.

\section{Results and discussion}

\subsection{Chemical characterization}

The BSI image of coquimbite sample studied in this work is shown in Fig. 1. Qualitative and semi-quantitative chemical composition shows a Fe and Al sulphate phase. The chemical analysis is represented as an EDS spectrum in Fig. 2. On the basis of semiquantitative chemical analyses the chemical formula was calculated as $\left(\mathrm{Fe}_{1.37}^{3+}, \mathrm{Al}_{0.63}\right)_{\sum 2.00}\left(\mathrm{SO}_{4}\right)_{3} \cdot 9 \mathrm{H}_{2} \mathrm{O}$.

\subsection{Thermal analysis}

The thermal analysis of coquimbite is illustrated in Fig. 3. To date, there have been no thermal analytical studies of coquimbite and related minerals $[21,22]$. There have been some differential thermal analysis study of a very wide range of sulphates from some years past [23]. The TG curve shows a total mass loss of $\sim 73.4 \%$ on heating to $1000{ }^{\circ} \mathrm{C}$ and is in agreement with the stoichiometric content of $\mathrm{H}_{2} \mathrm{O}$ and $\mathrm{SO}_{3}$ that correspond to $74.0 \mathrm{wt} \%$. A significant number of decomposition steps are observed according to the DTG curve in Fig. 3. Small mass loss steps are found at 37, 48 and $94{ }^{\circ} \mathrm{C}$. These mass los steps may be attributed to the loss of adsorbed water. Further mass loss steps are observed at 135 , 161,254 and $262^{\circ} \mathrm{C}$. These mass loss steps are assigned to the loss of water in stages. Two minor mass losses are found at 393 and $546{ }^{\circ} \mathrm{C}$. A very large mass loss occurs at $695^{\circ} \mathrm{C}$ and is assigned to the mass loss of $\mathrm{SO}_{3}$ due to sulphate decomposition. The total mass loss of water according to the given formula is $34.76 \%$ and the mass loss of sulphate as $\mathrm{SO}_{3}$ equals $34.73 \%$. Thus the theoretical total mass loss is $69.5 \%$. Thus the difference between the theoretical mass loss and the observed mass loss is $3.9 \%$ which is attributed to the loss of adsorbed water.

In the temperature range of $25-100{ }^{\circ} \mathrm{C}$, is observed a mass loss of about 5.2\%. The accepted formula by the IMA is $\mathrm{Fe}_{2}^{3+}\left(\mathrm{SO}_{4}\right)_{3} \cdot 9 \mathrm{H}_{2} \mathrm{O}$. This mass loss is attributed to the loss of adsorbed water, according to the equation:

$\mathrm{Fe}_{2}^{3+}\left(\mathrm{SO}_{4}\right)_{3} \cdot 9 \mathrm{H}_{2} \mathrm{O} \rightarrow \mathrm{Fe}_{2}^{3+}\left(\mathrm{SO}_{4}\right)_{3} \cdot 9 \mathrm{H}_{2} \mathrm{O}+\mathrm{H}_{2} \mathrm{O}$

In the temperature range of $500-700{ }^{\circ} \mathrm{C}$ a mass loss of $30.43 \%$. A strong exothermic reaction is observed at $641.4^{\circ} \mathrm{C}$. This mass loss is attributed to the loss of sulphate.

$\mathrm{Fe}^{3+}\left(\mathrm{SO}_{4}\right)_{3} \rightarrow \mathrm{Fe}_{2} \mathrm{O}_{3}+\mathrm{SO}_{3}$. According to this reaction the mass loss of $36 \%$ would be predicted based upon the formula $\mathrm{Fe}_{2}^{3+}\left(\mathrm{SO}_{4}\right)_{3} \cdot 9 \mathrm{H}_{2} \mathrm{O}$. A mass loss of $30.43 \%$ is observed for this step. 

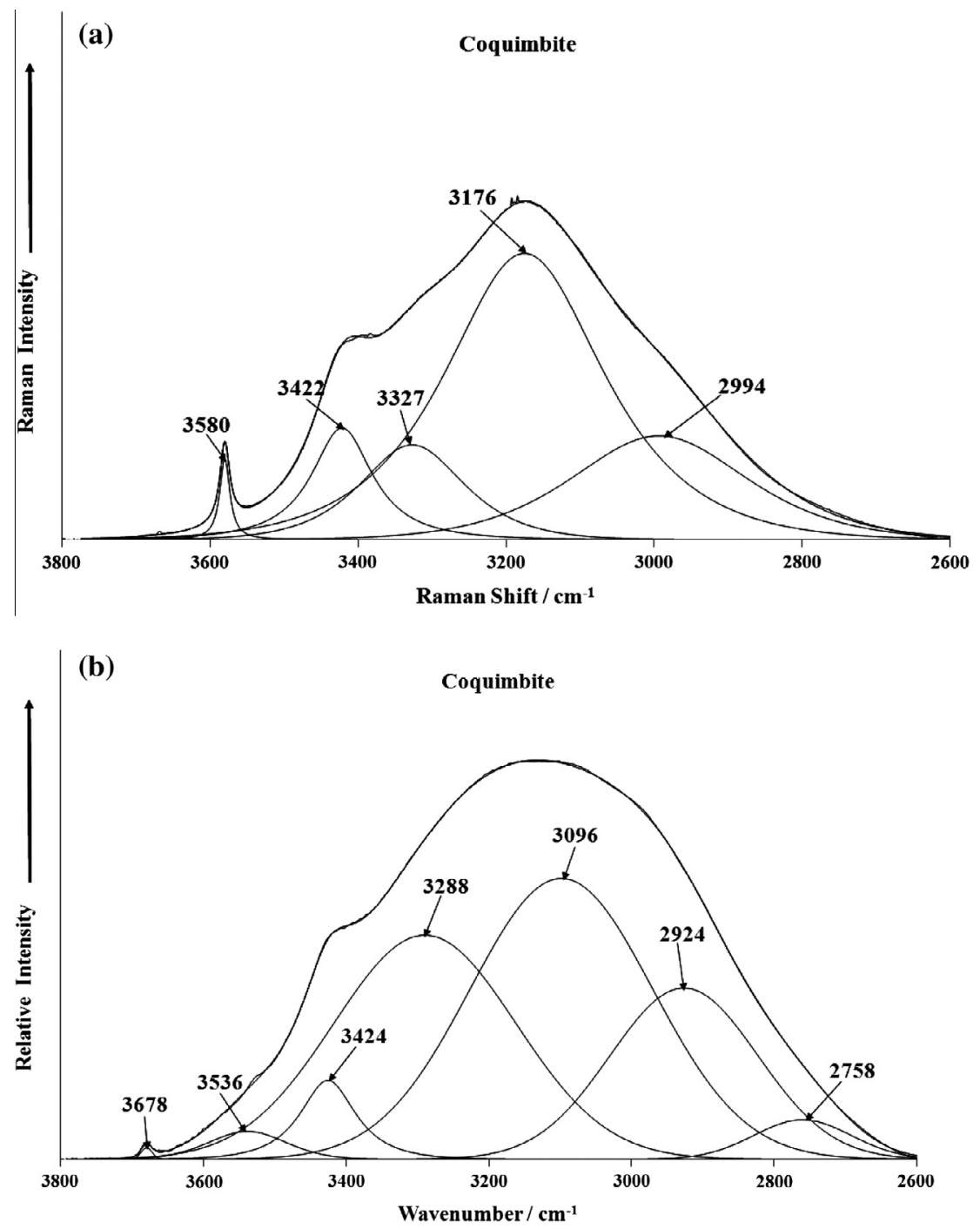

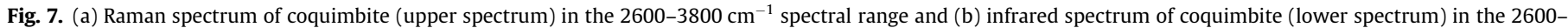
$3800 \mathrm{~cm}^{-1}$ spectral range.

\subsection{Vibrational spectroscopy}

Coquimbite as well as other iron sulphate minerals, were already investigated using NIR spectroscopy [20] and mid-infrared emission spectroscopy [24]. For NIR $6400-7400 \mathrm{~cm}^{-1}$ spectral region, spectrum of mineral coquimbite was characterized by overlap of the first $\mathrm{HOH}$ fundamentals and the $\mathrm{HOH}$ combination bands, and mineral showed intense bands at 6918 and $6646 \mathrm{~cm}^{-1}$. In NIR $4000-5500 \mathrm{~cm}^{-1}$ spectral region, bands were observed for coquimbite at 5214, 5144, 5066, 5010 and $4838 \mathrm{~cm}^{-1}$. In the high wavenumber region $\left(7500-1100 \mathrm{~cm}^{-1}\right)$ iron (III) minerals, and so did coquimbite, showed no bands [20]. Early mid-infrared spectroscopic studies have shown that the aqueous sulphate anion $\left(\mathrm{SO}_{4}\right)^{2-}$ produces four infrared absorption features at $\sim 1105, \sim 983, \sim 611$, and $\sim 450 \mathrm{~cm}^{-1}$ (corresponding to the antisymmetric stretch, $v_{3}$; symmetric stretch, $v_{1}$; asymmetric bend, $v_{4}$; symmetric bend $v_{2}$, respectively) of which only $v_{3}$ and $v_{4}$ are infrared active [24,25]. These vibrations are modified when the sulphate anion is present within a solid-state medium, such as a mineral with a repeating molecular order, resulting in the potential appearance of all four sulphate vibrational modes in the spectrum [24]. In mid-infrared emission spectroscopy investigations, spectra of sample containing both, coquimbite and paracoquimbite showed two clear $v_{3}$ features at 1180 and $1100 \mathrm{~cm}^{-1}$; where the shape of the $1100 \mathrm{~cm}^{-1}$ band suggested that there may be another weaker $v_{3}$ band at slightly lower frequency. There were also a strong $v_{1}$ feature present at $1013 \mathrm{~cm}^{-1}$, three bands at 685,650 , and $975 \mathrm{~cm}^{-1}$, and two $v_{2}$ features at 480 and $443 \mathrm{~cm}^{-1}$, with strong lattice modes occurring at $<350 \mathrm{~cm}^{-1}$ [24].

The Raman spectrum of coquimbite over the $100-4000 \mathrm{~cm}^{-1}$ spectral range is reported in Fig. 4a. This figure shows the position and relative intensity of each Raman band. The spectrum may be subdivided into sections depending upon the type of vibration being analysed. The infrared spectrum of coquimbite in the 500 $4000 \mathrm{~cm}^{-1}$ spectral region is illustrated in Fig. 4b. This spectrum shows the position and relative intensity of the infrared bands. This spectrum may be subdivided into subsections based upon the vibrational spectroscopic region. The results of the Raman spectroscopic analysis are summarised in Table 1. This Table shows the peak positions of the Raman and infrared bands and their assignment.

\subsection{Raman spectroscopy in the $800-1400 \mathrm{~cm}^{-1}$ spectral range}

The Raman spectrum of coquimbite over the $800-1300 \mathrm{~cm}^{-1}$ spectral range is provided in Fig. 5a. The spectrum is dominated by an intense Raman band at $1025 \mathrm{~cm}^{-1}$ and is assigned to the $\mathrm{SO}_{4}^{2-} \quad v_{1}$ symmetric stretching mode. Two shoulder bands are 

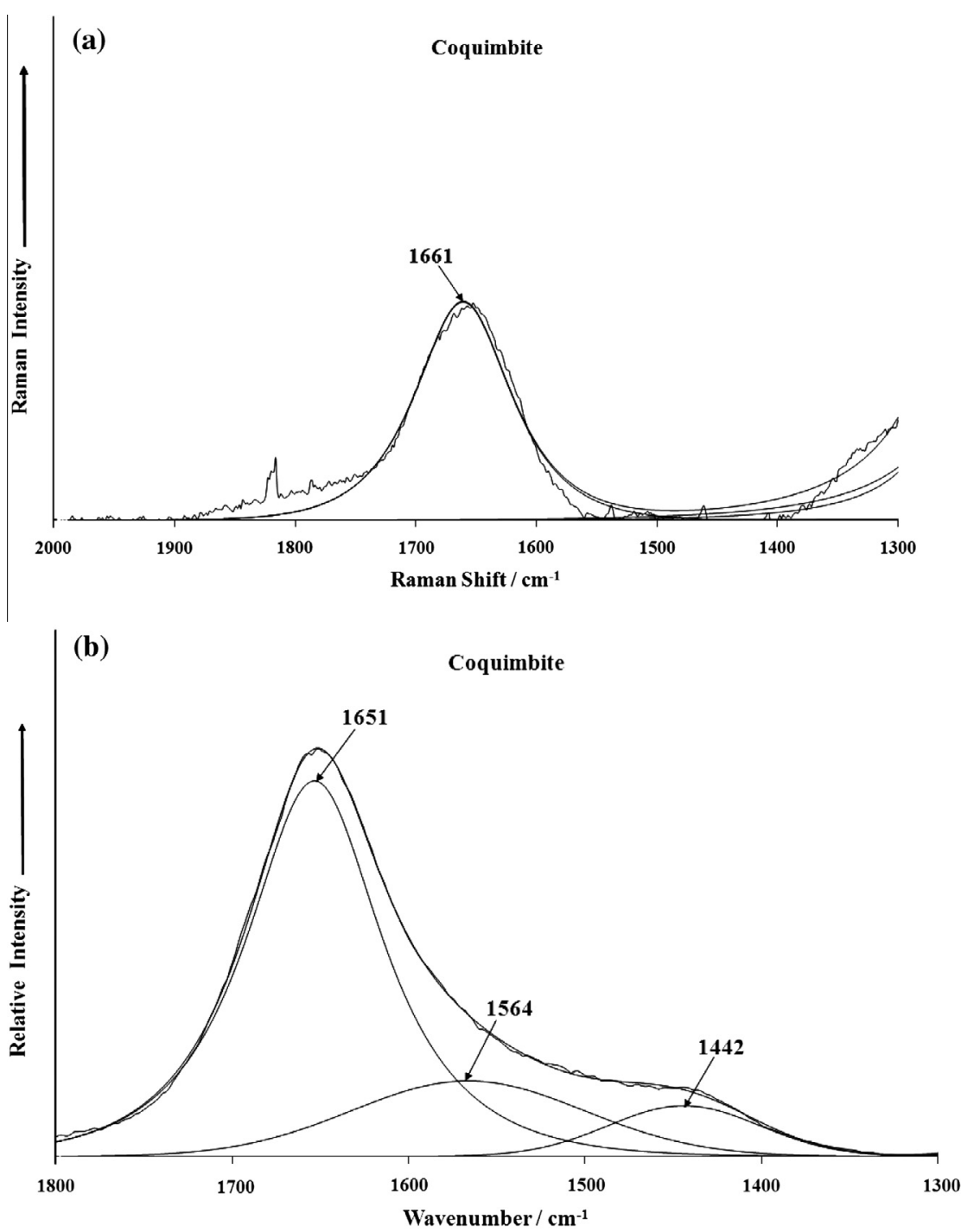

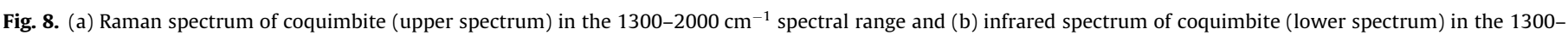
$1800 \mathrm{~cm}^{-1}$ spectral range.

observed at 1015 and $1037 \mathrm{~cm}^{-1}$. Four low intensity bands observed at $1095,1113,1165$ and $1201 \mathrm{~cm}^{-1}$ are attributed to the $\mathrm{SO}_{4}^{2-} v_{3}$ antisymmetric stretching modes.

\subsection{Infrared spectroscopy in the $500-1300 \mathrm{~cm}^{-1}$ spectral range}

The infrared spectrum of coquimbite in the $500-1300 \mathrm{~cm}^{-1}$ spectral range is given in Fig. 5b. The spectrum shows complexity with a significant number of overlapping bands. The infrared bands recognised at $1060,1100,1161$ and $1172 \mathrm{~cm}^{-1}$ are assigned to the $\mathrm{SO}_{4}^{2-} v_{3}$ antisymmetric stretching modes. The infrared bands at 1011 and $1024 \mathrm{~cm}^{-1}$ are attributed to the $\mathrm{SO}_{4}^{2-} v_{1}$ symmetric stretching mode.

3.6. Raman spectroscopy in the $300-800 \mathrm{~cm}^{-1}$ and in $100-300 \mathrm{~cm}^{-1}$ spectral ranges

The Raman spectrum of coquimbite in the $300-800 \mathrm{~cm}^{-1} \mathrm{spec}-$ tral range is shown in Fig. 6a. The Raman spectrum in the 100$300 \mathrm{~cm}^{-1}$ spectral range is provided in Fig. 6b. The complexity of the antisymmetric stretching region is reflected in the spectra of the $v_{2}$ bending region. A very intense Raman band is observed at $508 \mathrm{~cm}^{-1}$ with additional Raman bands at 414, 451, 463 and
$498 \mathrm{~cm}^{-1}$. These bands are assigned to the $v_{2}$ bending modes. Multiple bands are observed in the $400-500 \mathrm{~cm}^{-1}$ region for many minerals and are attributed to the $v_{2}$ bending modes. These multiple bands in this $v_{2}$ spectral region are in harmony with the multiple bands observed in the $v_{3}$ spectral region. These multiple bands may occur for several reasons one of which is the reduction of symmetry of the sulphate anion and secondly the fact that not all the sulphate anions are equivalent in the coquimbite structure. A comparison may be made with other sulphate bearing minerals. Bands are observed at 479,443 and $408 \mathrm{~cm}^{-1}$ for cyanotrichite, at 450 and $430 \mathrm{~cm}^{-1}$ for devilline, 498 and $471 \mathrm{~cm}^{-1}$ for glaucocerinite, at 475,445 and $421 \mathrm{~cm}^{-1}$ for serpierite and at 475 and 449 for ktenasite. For the mineral amarantite, a very intense Raman band is observed at $409 \mathrm{~cm}^{-1}$ with additional bands at 399, 451 and $491 \mathrm{~cm}^{-1}$.

The Raman bands at 599, 621 and $673 \mathrm{~cm}^{-1}$ are assigned to the sulphate $v_{4}$ bending modes. The observation of multiple bands in this spectral region is in accordance with a reduction in symmetry of the sulphate anion in the coquimbite structure. A comparison may be made with the vibrational spectra of amarantite. A series of low intensity Raman bands for amarantite found at 543, 602, 622 and $650 \mathrm{~cm}^{-1}$ are assigned to the $v_{4}$ bending modes. The Raman spectrum of ktenasite shows a single peak in the $v_{4}$ region 
at $604 \mathrm{~cm}^{-1}$. The Raman spectrum of devilline shows two low intensity bands at 668 and $617 \mathrm{~cm}^{-1}$; cynaotrichite two overlapping bands at 594 and $530 \mathrm{~cm}^{-1}$; the Raman spectrum of glaucocerinite shows two bands at 694,613 and $555 \mathrm{~cm}^{-1}$. The complexity of the symmetric and antisymmetric bending region shows a reduction in symmetry for these complex sulphate minerals. Raman spectra of the mineral phases for this region are different, and each phase has its own characteristic spectrum. The observation of multiple bands supports the concept of a reduction in symmetry of sulphate in the coquimbite structure. The Raman spectrum in the far low wavenumber region is shown in Fig. 6b. An intense Raman band at $284 \mathrm{~cm}^{-1}$ is assigned to $\mathrm{FeO}$ stretching vibrations. Other bands in this spectral region are simply described as lattice vibrations.

\subsection{Raman spectroscopy in the $2600-3800 \mathrm{~cm}^{-1}$ spectral range}

The Raman spectrum of coquimbite over the $2600-3800 \mathrm{~cm}^{-1}$ spectral range is displayed in Fig. 7a. The infrared spectrum over this spectral range is given in Fig. 7b. Both spectra are broad with several overlapping bands. The Raman spectrum shows well resolved Raman bands at 2994, 3176, 3327, 3422 and $3580 \mathrm{~cm}^{-1}$. These bands are assigned to the water stretching vibrations. The bands are less well resolved in the infrared spectrum. Infrared bands are noted at 2758, 2924, 3096, 3288, 3424, 3536 and $3678 \mathrm{~cm}^{-1}$. It is likely that the sharp Raman band at $3580 \mathrm{~cm}^{-1}$ is attributable to $\mathrm{OH}$ stretching vibrations.

\subsection{Raman spectroscopy in the $1300-2000 \mathrm{~cm}^{-1}$ spectral range}

The Raman spectrum of coquimbite over the $1300-2000 \mathrm{~cm}^{-1}$ spectral range is shown in Fig. 8a. This spectrum shows a broad Raman band at $1661 \mathrm{~cm}^{-1}$. This band is assigned to the water bending mode. The position of this band supports the concept of very strongly hydrogen bonded water in the coquimbite structure. The position of the water bands in both the Raman and infrared spectra shows that water is strongly hydrogen bonded in the coquimbite structure. Raman and infrared bands below say $4000 \mathrm{~cm}^{-1}$ are indicative of strongly hydrogen bonded water. Bands above $3400 \mathrm{~cm}^{-1}$ are indicative of weakly hydrogen bonded water in the coquimbite structure.

\section{Conclusions}

The techniques of electron microscopy, thermogravimetry and vibrational spectroscopy have been combined to determine the chemistry of the mineral coquimbite. Chemical analysis using an electron probe shows qualitatively that only Fe and $\mathrm{S}$ are present. On the basis of semiquantitative chemical analyses, the chemical formula was calculated as $\left(\mathrm{Fe}^{3+}{ }_{1.37}, \mathrm{Al}_{0.63}\right)_{\sum 2.00}\left(\mathrm{SO}_{4}\right)_{3} \cdot 9 \mathrm{H}_{2} \mathrm{O}$.

The TG curve shows a total mass loss of $\sim 73.4 \%$ on heating to $1000{ }^{\circ} \mathrm{C}$ in agreement with the stoichiometric content of $\mathrm{H}_{2} \mathrm{O}$ and $\mathrm{SO}_{3}$ that correspond to $74.0 \mathrm{wt} \%$.

Thermogravimetry proves the thermal decomposition of coquimbite takes place in a series of four major steps at 135 ,
161,254 and $262{ }^{\circ} \mathrm{C}$. A very large mass loss occurs at $695{ }^{\circ} \mathrm{C}$ and is assigned to the mass loss of $\mathrm{SO}_{3}$ due to sulphate decomposition.

Raman spectroscopy is a very powerful tool for the study of sulphate minerals. In this work we have used vibrational spectroscopy to study the mineral coquimbite, a mineral found in evaporate deposits and land surfaces with extreme aridity. Multiple antisymmetric stretching bands are observed as well as multiple bending modes suggesting a reduction in symmetry of the sulphate in the coquimbite structure.

\section{Acknowledgments}

The financial and infra-structure support of the Queensland University of Technology, School of Chemistry, Physics and Mechanical Engineering is gratefully acknowledged. The Australian Research Council (ARC) is thanked for funding the instrumentation. The authors would like to acknowledge the Center of Microscopy at the Universidade Federal de Minas Gerais (http://www.microscopia. ufmg.br) for providing the equipment and technical support for experiments involving electron microscopy. R. Scholz thanks to CNPq - Conselho Nacional de Desenvolvimento Científico e Tecnológico (Grant No. 306287/2012-9 and No. 402852/2012-5). Ž. Žigovečki Gobac thanks to Ministry of Science, Education and Sports of the Republic of Croatia, under Grant No. 119-00000001158.

\section{References}

[1] J.W. Anthony, R.A. Bideaux, K.W. Bladh, M.C. Nichols, Handbook of Mineralogy, vol. V, Borates, Carbonates, Sulfates., Mineral Data Publishing, Tucson, 2003.

[2] H. Rose, Annal. Phys. Chem. 27 (1833) 309-319.

[3] J.F.A. Breithaupt, Arnoldische Buchhandlung, Dresden and Leipzig, 1841.

[4] A. Arzruni, Zeit. Kryst. Min. 3 (1879) 516-524.

[5] G. Linck, Zeit. Kryst. Min. 15 (1889) 1-28.

[6] C. Palache, H. Berman, C. Frondel, Dana's system of mineralogy, 7th edition ed., 1951.

[7] A. Kovacs, Foldtani Kozlony 127 (1998) 353-370.

[8] J.H. Bernard, J. Hyršl, Granit, Prague, 2006.

[9] J. Hyršl, Miner. Welt 3 (2010) 68-71.

[10] D.M.C. Huminicki, F.C. Hawthorne, Can. Min. 38 (2000) 1425-1432.

[11] M. Mrose, D.E. Appleman, Zeit. Kryst. Min. 117 (1962) 16-36.

[12] J.-H. Fang, P.D. Robinson, Am. Min. 55 (1970) 1534-1539.

[13] C. Giacovazzo, S. Menchetti, F. Scordari, Rendiconti 49 (1970) 129-140.

[14] J. Majzlan, A. Navrotsky, R.B. McCleskey, C.N. Alpers, Eur. J. Min. 18 (2006) 175-186.

[15] F. Demartin, C. Castellano, C.M. Gramaccioli, I. Campostrini, Can. Min. 48 (2010) 323-333.

[16] F. Demartin, C. Castellano, C.M. Gramaccioli, I. Campostrini, Can. Min. 48 (2010) 1465-1468.

[17] F. Demartin, C. Castellano, C.M. Gramaccioli, I. Campostrini, Min. Mag. 74 (2010) 375-377.

[18] P.D. Robinson, J.H. Fang, Am. Min. 56 (1971) 1567-1572.

[19] F.C. Hawthorne, S.V. Krivovichev, P.C. Burns, The Crystal Chemistry of Sulfate Minerals, Sulfate Minerals: Crystallography, Geochemistry, and Environmental, significance ed., Mineralogical Society of America, Chantilly, Virginia, 2000.

[20] R.L. Frost, R.-A. Wills, W. Martens, M. Weier, B.J. Reddy, Spectrochim. Acta 62A (2005) 42-50.

[21] R. Scharizer, Zeit. Kryst. Min. 56 (1921) 353-385.

[22] R. Scharizer, Zeit. Kryst. Min. 65 (1927) 335-360.

[23] G. Cocco, Periodico di Min. 21 (1952) 103-138.

[24] M.D. Lane, Am. Min. 92 (2007) 1-18.

[25] K. Nakamoto, Infrared and Raman Spectra of Inorganic and Coordination Compounds, Wiley \& Sons, New York, 1986. 